\title{
Hybridizing UN Peace Operations: The Role of the European Union and Canada
}

\author{
Kristine St-Pierre ${ }^{1}$
}

\begin{abstract}
The prevalence of hybrid peacekeeping missions on the international stage underscores the increasing flexibility with which the UN can meet the peacekeeping demand. This flexibility results from the growing number of actors that the UN can rely on, allowing in turn for more diverse responses to conflict. However, current confusion surrounding hybrid missions points to the need to further clarify the role of regional actors in hybrid missions and elaborate on the implication of these missions for UN peacekeeping. This paper thus discusses the importance of hybrid missions in peace operations by examining the current nature of European Union (EU) and Canadian contributions to peace operations, and by analysing the implications of these contributions for hybrid missions and UN peacekeeping in general.
\end{abstract}

Keywords: UN peacekeeping, hybrid peace operations, regional actors, EU and Canada contributions to UN peacekeeping

\footnotetext{
${ }^{1}$ Kristine St-Pierre is presently interning at the Henry L. Stimson Center in Washington, D.C., where she is conducting research with the Future of Peace Operations programme. Ms St-Pierre holds an M.A. (Conflict Analysis and Resolution) from the Norman Paterson School of International Affairs (NPSIA), Carleton University.
} 


\section{Introduction}

Hybrid peacekeeping missions-or missions in which United Nations(UN) and non-UN forces share, under various frameworks, peacekeeping responsibilities-are not new. According to Bruce Jones and Feryal Cherif (2004), most contemporary or post-1990 UN missions have been hybrid in nature. Hybrid operations are particularly important when considering the UN's deepening responsibilities in peace and security, as manifested through the increasing strain in recent years on its capacity to deploy and sustain peacekeeping missions. The prevalence of these missions on the international stage also reveals the significant growth in the number and involvement of regional actors in peace operations. This trend in turn translates into greater flexibility in the field, by offering the UN different avenues for meeting the peacekeeping demand. However, as hybrid missions offer greater possibilities, there is still confusion regarding the operational and organizational nature of hybrid missions and their implications for conflict management (Jones \& Cherif 2004). This confusion points to the need to further clarify the role of regional actors in hybrid missions (i.e., how do regional actors contribute to hybrid missions?) and to elaborate on the implication of these missions for UN peacekeeping (i.e., how do hybrid missions affect UN peacekeeping?).

To achieve this task, this paper first discusses the importance of regional actors in conflict management, following which it considers the role of hybrid missions in peace operations. The paper then examines the current nature of European Union (EU) and Canadian contributions to peace operations, and analyses the implications of these contributions for hybrid missions and UN peacekeeping in general. ${ }^{2}$ The paper's focus on the EU and Canada specifically stems from their shared support for a multilateral approach and for strengthening UN and regional capacity in responding to conflicts. In addition, crisis management is often described as a particular area where cooperation between the EU and Canada is exceptionally good, and where future joint efforts are more than likely. As a result, it seems appropriate to look at the different ways both can contribute to peace operations, and to the UN.

\section{Regional Actors in Peace Operations: the Role of Hybrid Missions}

Following a downturn in UN peacekeeping missions in the mid-to-late 1990s, the UN has since witnessed a deepening of its responsibilities in peace and security (see Durch \& Berckman 2006b). This can be seen from the increase in the number, size and complexity of UN peacekeeping missions since the beginning of the $21^{\text {st }}$ century. There are presently over 100,000 military, police and civilian personnel (of which more than 80,000 are uniformed personnel) deployed as part of $15 \mathrm{UN}$ peacekeeping missions (DPKO 2007b). ${ }^{3}$ With the new mission to Darfur currently underway, this number can only increase. ${ }^{4}$

\footnotetext{
${ }^{2}$ It should be mentioned that the EU does not consider itself a typical regional organisation as foreseen by Chapter 8 of the UN Charter; it is nevertheless a regional actor (or as some argue global actor) in the field of crisis management.

${ }^{3}$ In fact, the Center for International Cooperation's 2007 Annual Review of Global Peace Operations mentions that UN deployments have seen a five-fold increase between 2000 and 2005. The number of uniformed personnel also saw an increase of 10,000 since last year (CIC 2007).

${ }^{4}$ In a press release in October 2006, Jean-Marie Guehenno, the undersecretary-general for peacekeeping warned that this number could reach 140,000 with a year (Leopold 2006).
} 
While this surge in UN peacekeeping missions clearly reveals the evolving and crucial role of UN peacekeeping in conflict management, it is also contributing to the dramatic strain on the UN's capacity to undertake and sustain substantial missions. This strain is compounded by the organisation's increasing financial burden, which has for the first time in UN history surpassed the $\$ 5$ billion mark (UNOG 2006). Given these constraints, strategic partnerships between regional actors and the UN are increasingly looked upon as the preferred option for meeting the peacekeeping demand (CIC 2006).

The potential role of regional actors and organizations in conflict management was underscored by the 2004 Report of the Secretary General's High Level Panel on Threats, Challenges and Change and the Secretary General's 2005 report In Larger Freedom. The High Level Panel called for a greater reliance on Chapter 8 of the UN Charter and a more integrated approach to peacekeeping between the UN and regional organisations (UN 2004). ${ }^{5}$ In Larger Freedom went further in suggesting the establishment of formal agreements between the UN and regional peacekeeping capacities that would allow for greater exchanges in early warning information and help in the areas of training and logistics (UN 2005). The report called on the establishment of "an interlocking system of peacekeeping capacities that will enable the United Nations to work with relevant regional organisations in predictable and reliable partnerships" (Ibid., 31). The report further acknowledged that the need for rapid action could not be achieved solely through the mechanisms of the UN, and urged UN members to improve the UN's deployment options through the creation of strategic reserves that could deploy rapidly within the framework of the United Nations arrangements. In this regard, the report welcomed, for example, the decision by the European Union and the African Union to create highreadiness standby brigades that could be used to reinforce UN missions, and invited other nations to develop similar capacities and place these at the disposal of the UN. The High Level Panel also highlighted NATO's increasing role in peacekeeping, though it cautioned that such capacity to undertake stand-alone operations should not be used outside a UN framework. In sum, the emergence of regional actors on the international scene, namely the EU, NATO, the AU, and ECOWAS, and their potential deployment capacity is beneficial for the UN as they provide the UN with the opportunity to utilize complementary capabilities through hybrid missions. The nature of these missions and their role in peace operations are explored next.

\subsection{Hybridizing UN peacekeeping missions}

Jones and Cherif (2004) identify four types of hybrid missions, which differ in the level of integration between the UN and non-UN entities. These are described in Table 1. Each type of hybrid mission can be further differentiated with respect to the nature of the nonUN component, whether a regional organization (RO), a multinational force or a bilateral operation. ${ }^{6}$

\footnotetext{
${ }^{5}$ Chapter 8 refers to operations authorized by the Security Council, but led by other actors, such as regional organizations and coalitions of willing states.

${ }^{6}$ One example of a hybrid mission includes Afghanistan, where a UN political mission, the United Nations Assistance Mission in Afghanistan (UNAMA), is working alongside the NATO-led ISAF mission. A hybrid UN-AU peacekeeping force is also underway in Darfur. This hybrid force, however, would be much more integrated than the operation in
} 
Table 1: Hybrid Missions and their Characteristics

\begin{tabular}{|l|l|}
\hline $\begin{array}{l}\text { TYPES OF HYBRID } \\
\text { MISSIONS }\end{array}$ & CHARACTERISTICS \\
\hline INTEGRATED & UN and ROs operate with single or joined chain of command \\
\hline COORDINATED & UN and ROs are coordinated but operate under different chains of command \\
\hline PARALLEL & UN deploys alongside other org.; no formal coordination \\
\hline SEQUENTIAL & UN precedes or follows other forces \\
\hline
\end{tabular}

Source: Jones and Cherif 2004.

The potential complementary capability offered by regional actors is important considering the ongoing challenges facing the deployments of UN peacekeeping operations. In general, UN deployments are marked by limited rapidity, a lack of flexibility and delays in the approval of mandates. The UN also faces a growing reluctance on the part of Western countries to deploy troops-especially larger contingents — under UN command (Liégois 2006). ${ }^{7}$ This has led since the mid-1990s to a dramatic decline in the level of troop contribution by Western states to UN-led operations and to an increasing reliance on developing countries to offer troops. ${ }^{8}$ While these contributions are much needed, the large provision of military personnel by developing countries has caused serious operational consequences in peace operations, as troops are often poorly and inadequately trained, and they suffer from a limited pool of specialized units and from delays in deployment. It is also fair to say that regional actors and ad hoc coalitions rarely enjoy the same level of legitimacy than the UN (CIC 2006). ${ }^{9}$

In fact, as argued in the Center for International Cooperation's (CIC) 2006 Annual Review of Global Peace Operations, hybrid missions may prove to be the best option for the future, owing to their combination of UN legitimacy and regional or local capacity. While there are significant differences in the capacity level of regional actors, in general, hybrid missions are said to be advantageous for several reasons. Hybrid missions can alleviate the UN's burden by dividing peacekeeping responsibilities between the UN and the regional actor, or by assigning the latter with the entire mandate. Regional actors in hybrid missions can also deploy in advance of a UN force, thereby providing the UN with more time to build-up and deploy a mission, and can help reinforce UN missions at short notice. Finally, hybrid missions are believed to be more robust and capable than UN

Afghanistan, the latter of which can be qualified as coordinated rather than integrated. See Jones and Cherif 2004; and Durch and Berkman 2006a,b.

${ }^{7}$ It should be noted that the concentration of Western countries on providing logistics, planning and command \& control also involves significantly lower political and human risks than that of deploying a battalion (Liégois 2006).

8 As of 31 October 2006, the top 10 contributors of uniformed personnel to UN peacekeeping were Pakistan, Bangladesh, India, Jordan, Nepal, Ghana, Uruguay, Ethiopia, Nigeria and South Africa. Together, these countries accounted for 60 per cent of all UN military and police personnel. Since December $31^{\text {st }}, 2006$, Italy and France are now $8^{\text {th }}$ and $10^{\text {th }}$ respectively (replacing Ethiopia and South Africa). This is due to their contribution to UNIFIL, the UN Interim Force in Lebanon. See DPI 2007.

${ }^{9}$ The African Union (AU) force in Darfur is a specific example of an organisation who has enjoyed greater legitimacy than a UN mission. Indeed, the blockage, until recently, of the UN (as part of a UN-AU hybrid force) in Darfur demonstrates that even UN legitimacy is not always recognized as such. 
missions on their own. ${ }^{10}$ This is especially the case as regional organisations and ad hoc forces have proven more willing to undertake deployments under Chapter 7 of the UN Charter. ${ }^{11}$ (See Durch \& Berckman 2006a; Jones \& Cherif 2004; CIC 2006)

In this context, Bruce and Cherif (2004) project that UN-commanded peacekeeping operations will continue in the future especially in Africa, and see the overall response as being met through hybrid operations. As mentioned earlier, the prevalence of hybrid missions underscores the increasing flexibility with which the UN can meet the peacekeeping demand. This flexibility results from the growing number of actors that the UN can rely on, allowing in turn for more diverse responses to conflict. The presence of numerous actors, however, does not guarantee that an intervention will occur, as other factors enter into play. Most often, deployments occur where national and/or security interests can best be served, though the availability of funding and equipment are also important factors in the decision to send troop and can significantly restrict the scope and duration of interventions (Durch \& Berckman 2006b). Still, it is argued that the probability of regional actors to get involved in a hybrid mission will depend on the extent to which such deployment can, first and foremost, serve their interests.

In addition, Jones and Cherif (2004) maintain that there is still confusion, both within policy circles and within the UN itself, as to the exact nature of hybrid missions and their implications within the broader field of conflict management. In particular, they note the UN's (including the Department of Peacekeeping Operations and Secretariat) limited capacity to manage the hybrid nature of operations and their increasingly large civilian component (especially with respect to planning of the civilian dimension). As a result, they specify that UN operations will often be preceded by force multiplier components, though they predict that the availability of such mission will remain ad hoc and inconsistent.

In this regard, it is fair to say that hybrid missions need "a comprehensive approach, coordinated and planned not in isolation, but in close cooperation between the parties involved" (Eide 2006, 51-52). However, the development of partnerships between the UN and regional actors raises questions regarding the strategic nature of these partnerships and whether they should be formed through established collaborations between the UN and other entities or on a case-by-case basis (Guicherd 2006). Moreover, while the UN welcomes the desire of regional actors to conduct operations (either under Chapter 8 of the UN Charter or by request), it is important that efforts geared towards strengthening regional and local peacekeeping capacities complement UN efforts and works towards strengthening the organisation rather than undermining it. In trying to understand how regional actors can contribute to and support the deployment of hybrid missions, I now turn to an examination of European Union and Canadian contributions to peace operations, and analyze the implications of these contributions for hybrid missions and $\mathrm{UN}$ peacekeeping in general.

\footnotetext{
${ }^{10}$ Nevertheless, regional actors, especially in Africa, may not always be adequate and sufficiently credible for a mission to succeed and are often no more efficient than the UN. According to Cilliers (69), for example, most missions in Africa are "significantly beyond African resources."

${ }^{11}$ Operations with Chapter 7 mandates provide peacekeepers with greater flexibility to use force.
} 


\section{European Union Contributions to Crisis Management}

The EU is a relatively new comer on the peacekeeping front, its first mission dating back to 2003 in Macedonia. The EU has since conducted 16 missions, some of which were in close cooperation with the UN, and has extended beyond its immediate geographic reach deploying military, police, and civilians to the Balkans, Africa, Southeast Asia, and the Middle East (see Table 2). These missions were conducted under the European Security and Defence Policy (ESDP), which according to Jim Choos, Director at the Council Secretariat, is in many ways geared towards helping the UN "fulfill its increasing burden" $(2007,15)$.

Table 2: EU-Led Civilian and Military Crisis Management Missions

\begin{tabular}{|c|c|c|}
\hline $\begin{array}{l}\text { TYPE } \quad \text { OF } \\
\text { MANAGEMENT }\end{array}$ & CRISIS & CORRESPONDING MISSIONS \\
\hline $\begin{array}{l}\text { CIVILIAN } \\
\text { MANAGEMENT }\end{array}$ & CRISIS & $\begin{array}{l}\text { Current Operations: } \\
\text { - } \\
\text { EUPM in Bosnia-Herzegovina (2003-present) } \\
\text { EUSEC DR Congo (2005-present) } \\
\text { EU BAM Rafah in Palestinian Territories (2005-present) } \\
\text { - } \\
\text { EUJUST LEX in Iraq (2005-present) } \\
\text { component) Support to AMIS II in Darfur (2005-present; civ-mil } \\
\text { : EUPM in Palestinian Territories (EUPOL COPPS; 2006- } \\
\text { present) } \\
\text { EUPT in Kosovo (2006-present) } \\
\text { - } \\
\text { EUPOL AFGHANISTAN (deployed in June 2007) } \\
\text { EUPOL RD CONGO (deployed in July 2007) } \\
\text { ESDP mission to Kosovo (expected deployment in 2007) } \\
\text { Completed Operations: } \\
\text { (EUPOL Proxima; 2003-05 } \\
\text { EUJUST THEMIS in Georgia (2004-05) } \\
\text { - } \\
\text { Aceh Monitoring Mission (AMM; 2005-06) } \\
\text { EUPAT in the former Yugoslav Republic of Macedonia (2005- } \\
\text { E6) } \\
\text { EUPM in DRC (EUPOL Kinshasa; 2005-2007) }\end{array}$ \\
\hline $\begin{array}{l}\text { MILITARY } \\
\text { MANAGEMENT }\end{array}$ & CRISIS & $\begin{array}{l}\text { Current Operations: } \\
\quad \text { EUFOR in Bosnia-Herzegovina (Operation Althea; 2004-present) } \\
\text { Interim EU Force to Chad (under discussion) } \\
\text { Completed Operations: } \\
\quad \text { EUFOR in the former Yugoslav Republic of Macedonia (Operation } \\
\text { Concordia; 2003) } \\
\text { EUFOR Bunia, DRC (Operation Artemis; 2003) } \\
\text { - } \quad \text { EUFOR RD Congo (2006) }\end{array}$ \\
\hline
\end{tabular}

Source: European Council 2007 (data as of July 2007).

In September 2003, the EU and UN signed a "Joint Declaration on EU-UN Cooperation in Crisis Management" calling for the practical cooperation in the field of crisis management, planning, training, communication and best practices, greater exchange of information, and coordination of activities and priorities. The importance of such developments were reaffirmed in the European Security Strategy (ESS), adopted in December 2003, which emphasizes multilateral responses to security questions and the 
need to reinforce international organisations. Since then, joint efforts between the EU and UN have substantially intensified, and EU developments in crisis management and deployments under an EU flag have been welcomed by the UN. The possibility of "relying on a more active, capable and coherent EU as an operational partner committed to "effective multilateralism" constitutes a significant attraction to the UN (Graham 2004, 10). However, it is important to ensure that EU capacities serve to enhance rather than weaken the UN. The next section thus examines EU developments in both military and civilian crisis management and identifies the opportunities and challenges to greater EU-UN cooperation.

\subsection{Military crisis management}

In 2004, the EU and UN adopted an "Agreement on Cooperation in Military Crisis Management" (2004), establishing two frameworks for engaging the EU in UN operations, at the request of the UN or under a UN mandate (Liégois 2006). They are the 'Bridging Model' and 'Standby Model.' The 'Bridging model' envisages the rapid deployment of an EU force immediately following a cease-fire or in response to an emerging crisis. The force would provide an immediate presence and show of force on the ground, and would give the UN time to deploy a larger follow-on operation. Examples of bridging forces include the take over of the UN task force by the European police mission in Bosnia and Herzegovina in 2003, and the deployment, that same year, of an EU military force to Bunia, DRC, allowing the UN to strengthen its peacekeeping mission (MONUC) and expand its mandate. The 'Standby model', for its part, foresees a number of EU forces kept on standby to deploy at the UN's request as a stand-alone operation or in the initial phase of a larger UN operation. Forces could also intervene to assist peacekeepers or get people out.

On the basis of these models, the EU has developed two capacities that could help boost its contributions to UN peacekeeping (Choos 2007). The first is the development of Battlegroups (BGs) aimed at reinforcing the ESDP's military capabilities. Declared operational in January 2007, BGs are forces composed of 1,500 troops deployable within a timeframe of 5 to 10 days and sustainable in the field for up to 120 days. Each BG also has a force headquarter and pre-identified logistics and transport components. There are presently two BGs on standby that are able to deploy simultaneously on different missions. The second capacity is the setting up of a civilian-military cell to improve planning capacity in integrated missions.

\subsection{Civilian crisis management}

In June 2000, the EU identified four priorities for civilian crisis management: police, rule of law, civilian administration and civil protection. ${ }^{12}$ The EU also set up quantitative targets for meeting these priorities, including the provision of an available force for international service of up to 5,000 civilian police (1,400 of which are part of a rapid response force which can deploy on a 30-day notice), as well as 200 judges, lawyers, and corrections officers (60 of which can deploy on a 30-day notice) (EC 2007). While these

\footnotetext{
${ }^{12}$ The establishment of monitoring capacities is identified as a possible fifth priority area.
} 
quantitative targets have been largely surpassed (based on voluntary Member State commitments), the EU is now concentrating on developing the qualitative aspects of its civilian approach, concentrating on the development of capabilities using a needs-based approach (Goulay 2005).

In line with this new focus, in 2005, new goals were set for improving the civilian dimension of ESDP. ${ }^{13}$ These goals are based on the development of capacities that will enable the EU to deploy integrated civilian crisis management packages, conduct simultaneous civilian missions that are sustainable over a longer period of time, deploy at short notice, work in close-cooperation with the military, and respond to requests by international organisations, with particular attention given to the UN (Goulay 2005).

\subsection{Opportunities and challenges to greater EU-UN cooperation}

While the EU has conducted both military and civilian missions, the vast majority of ESDP missions to date (as identified in Table 2) have been civilian or civilian-oriented. In fact, the EU has made fastest operational progress with respect to civilian capabilities for crisis management and more success has been achieved in police missions than in military ones. This has led many scholars and policy makers to view the EU's comparative advantage to be in the civilian field (Liégois 2006). Many also believe that much can be learned from the EU's integrated concept of civilian-military crisis response (see Earle 2004; GCSP 2003). As Liégois argues, "The EU appears as a particularly promising actor owing to its capacity to effectively combine the military and civilian components required in contemporary multidimensional peacekeeping operations" (2006, 160; own translation). This capacity, combined with the EU's "new focus on creating modular and potentially multifunctional packages, capable of being tailored to the specific needs of a crisis at short notice" serve as distinct advantages for conflict prevention and crisis management (Goulay 2005, 4). Battlegroups (BGs), for example, could prove to be effective as an initial entry force to secure vital assets, or as an emergency force to establish a deterring presence on the ground while awaiting the deployment of a larger and more robust peace-enforcement mission or follow-on peacekeeping force. In fact, BGs were envisaged for missions comparable in size, capabilities and requirements to that of Operation Artemis in the DRC - the EU's first autonomous mission without reliance on NATO assets, with France as the framework nation-and as a result, BGs could prove credible and effective in similar kinds of missions.

Despite these developments, the EU still demonstrates serious flaws with respect to peacekeeping, affecting its credibility and its effectiveness with respect to the actions it undertakes (Liégois 2006). For example, Earle (2004) argues that the EU faces a deficit in military and police capacity that can be deployed as part of post-conflict peace operations. She identifies two types of military gaps: the first between forces committed and their ability to deploy, and the second between the declared capacity and the actual trained, deployable and interoperable capacity, referring specifically to the "triple-hated" nature of EU troops as counted as part of available EU, NATO and UN contributions.

\footnotetext{
${ }^{13}$ These goals were set out in the Civilian Headline Goal 2008.
} 
Earle also identifies a police gap between the number of police officers committed to operations and the actual number available to deploy.

Another concern is the question of whether BGs will be able to deploy in larger and more demanding types of operations. As the usual deployment time for a UN peacekeeping force takes up to six months, BGs would need to be capable and willing to remain in theatre for longer periods of time. Moreover, as force generation and deployment are the sole responsibility of the member states, BGs are required to find their own transport to a mission area. This issue will remain a major challenge for the EU, for as long as airlift capacity remains limited. It is also well-known that the EU faces a lack of adequate investment in defence. In this regard, while the operational capacity demonstrated in recent EU operations could foresee the deployment of BGs to other continents, the limited size and capabilities of BGs will inevitably limit their reach to that of responding and solving local and/or limited size crises. As a result, it is reasonable to think that future out of area missions will not be feasible without the appropriate military capabilities and force structure, as well as the adequate financial means.

Apart from questions of capabilities, policy questions also present obstacles to the deployment of BGs. One potential challenge will be meeting the short timeframe between the approval of a BG and its deployment. This will depend on rapid political decisionmaking at both the member state and Council levels. In addition, the success of the BG concept will emanate from the ability of member states to come to a consensus, or the ability of some members to pressure others in deploying the force. Consequently, powerful nations within the EU will likely keep their leverage and dictate when and where BGs are used.

More specifically, this means that EU deployments will likely concentrate in regions that are of strategic interest to its members. The EU's main engagement under the ESDP is in the Balkans, a situation, which according to Liégois (2006) is not likely to change for several years to come. Yet, the EU has also clearly demonstrated its capacity and intent of conducting both military and police operations in Africa. ${ }^{14}$ As a matter of fact, while Europe's primary interest lies in the security of its borders, Africa is also extremely important strategically, especially in terms of the fear and political drawbacks generated by an increase in refugees and asylum seekers (Belliard 2007). Europe thus has an interest in seeing that African conflicts are contained (Ibid.).

Other outstanding issues have to do with the chain of command in military operations, i.e., the control over the chain of command in joint operations, the EU's involvement in planning of UN operations, and the arrangements for the transfer of authority from EU to UN mission (ISIS 2004). The latter component is particularly important as the EU's exit strategy, in most situations, remains a UN operation. On these issues, the deployment of the UN mission to Lebanon (UNIFIL) following the July 2006 crisis, is an interesting case. Although it was difficult to get member states to commit troops and uphold their

${ }^{14}$ While some (see Moens 2006) argue that ESDP missions should concentrate on stabilizing European borders as NATO devotes itself to areas outside of Europe, the reality is that NATO will not, at least in the foreseeable future, deploy troops to Africa. 
commitments (in addition to delays involved in requiring parliament approval), a force of over 13,024 was eventually deployed with Italy contributing 2,488 soldiers, France, 1,610, Spain, 1,082, and Germany, 782 (DPKO 2007a). While this major involvement in UNIFIL by EU members is proof of the continued reliance on the UN in situations where the deployment of regional actors or ad hoc forces would be controversial, it also points to the ability of EU members to retain command and control over their contingents, even when deployed under a UN flag.

Finally, the EU's lack of commonality and cohesiveness in both decision-making and capability structure is possibly the EU's greatest challenge in crisis management (see Liégois 2006). As Eide $(2006,46)$ argues, the EU "has precisely the multifaceted nature that is needed to take an integrated approach to [peace operations]" but it needs "to get its act together to reap this potential synergy." In other words, a coherent strategy and "collective will to deploy" will be crucial for the deployment of police and military crisis management missions (Earle 2004).

\section{Canadian Contributions to Peace Operations}

Canada, in comparison to the EU, has participated in almost every mission since the inception of peacekeeping and Canadian soldiers and civilian police officers are recognized worldwide as being among the finest peacekeepers. Canada has also always been a strong supporter of UN peacekeeping, although its role in UN peace operations in the last 15 years has been decreasing. Canada's troop contribution has suffered a stark decline since the mid-1990s, counting a total of 139 military observers, police and troops to UN peacekeeping missions as of March 2007 (see Table 3) (DPKO 2007a). Out of 114 troop contributing countries, Canada ranks $59^{\text {th }}$. Canada's financial contribution to the UN peacekeeping budget is minimal, contributing 3\% of the 2006 assessed contributions to UN Peacekeeping Budget of about $\$ 4.75$ billion (UNAC 2007). Although Canada clearly acknowledges that peacekeeping is beneficial to the international community, these figures reflect an increasing gap between Canada's long history and exemplary record in UN peacekeeping and its present contribution in terms of UN peacekeeping personnel and percentage of cost of peacekeeping missions.

Table 3: Current Canadian Contributions to UN Peacekeeping Operations

\begin{tabular}{|l|l|}
\hline UN PEACEKEEPING OPERATIONS & CONTRIBUTIONS \\
\hline UN Stabilization Mission in Haiti (MINUSTAH) & 66 (62 police; 4 troop) \\
\hline UN Organisation Mission in the DRC (MONUC) & $\begin{array}{l}8 \text { (military observer - } \\
\text { MO) }\end{array}$ \\
\hline UN Assistance Mission for Iraq (UNAMI) & 1 (MO) \\
\hline $\begin{array}{l}\text { UN Disengagement Observer Force in the Golan } \\
\text { Heights (UNDOF) }\end{array}$ & 2 (troop) \\
\hline UN Forces in Cyprus (UNFICYP) & $\begin{array}{l}35 \text { (troop) } \\
\text { MO) }\end{array}$ \\
\hline UN Mission in Sudan (UNMIS) & 6 (police) \\
\hline UN Integrated Mission in Timor-Leste (UNMIT) & 5 (police) \\
\hline UN Operations in Côte d'Ivoire (UNOCI) & \\
\hline
\end{tabular}




\begin{tabular}{|l|l|}
\hline $\begin{array}{l}\text { UN Truce Supervision Organisation in the Middle East } \\
\text { (UNTSO) }\end{array}$ & (police) \\
\hline
\end{tabular}

Source: DPKO 2007a (data as of 30 June 2007).

The trend in Canadian commitments to peace operations can be described as a clear move away from UN-led peacekeeping and a move towards NATO or UN-mandated stabilization missions. Canada has taken greater interest in missions run by NATO partly because of UN failures in the 1990s and the increasing fear of placing Canadian soldiers in situations where they are vulnerable. In addition, the "military structure [in NATO-led operations] is better defined, the number of troops deployed is larger, the level of support is greater, and partner nations are generally better equipped and trained than in typical UN-commanded missions" (Dorn 2006, 16). Canada's interest in NATO also reflects a rapprochement vis-à-vis the US and the emergence of 'new' security issues such as terrorism. This can be seen from Canada's present contribution of 2,500 troops to the NATO-led International Security Assistance Force (ISAF) in Afghanistan.

Despite the trend identified above, Canada, just like the EU, remains committed to the UN and to a multilateral approach, as highlighted by its focus on the role of international organisations as the basis for stability and peace within the international system (IPS 2005). These commitments have resulted in the development in recent years of a number of initiatives. As these initiatives were created to support Canada's desire for a larger role in conflict management, in doing so, they also demonstrate direct implications for UN peacekeeping. These initiatives are briefly described below.

\section{1) Creation of the Stabilization and Reconstruction Task Force (START)}

START was created in 2005 to assess the extent of crises around the world, and, drawing on expertise from across government and in collaboration with task forces from partner countries, to promote faster and more coordinated responses by the Government in support of stabilization and reconstruction efforts. The task force also aims to be effective in providing support to the UN when responding to crises (Government of Canada 2007; Hamilton 2007).

\section{2) Increasing role of Canadian civilian police in peacekeeping missions}

Canadian police officers, coordinated by the Royal Canadian Mounted Police, are increasingly taking part in peacekeeping missions. Their activities include training local police, reforming and professionalizing police organisations, strengthening security and reinforcing local authority, and promoting civil-military relations. Canada, for example, contributes 12 police experts in Darfur, the largest police contribution to the area. Canadian police personnel (up to 100 civilian police and 25 experts on police services) also provide training and expertise to the Haitian National Police (RCMP 2007).

\section{3) Creation of the Standing Contingency Force}

Canada recently developed a Standing Contingency Force to enhance its ability to respond quickly to international crises. The Force consists of approximately 1000 soldiers deployable within 7 to 10 days notice, with the aim of providing an initial stabilizing 
presence on the ground to facilitate, if needed, the deployment of a larger, follow-on force (UNAC 2007). ${ }^{15}$

\section{4) Development of civilian rosters}

The creation of rosters or catalogues, such as the roster developed by CANADEM for example, can help to circumvent a lack of political will by individual states and can also enable a more timely deployment of peacekeeping forces. Rosters keep an updated database of civilian experts that can deploy on short-notice to peace missions.

\section{5) Deployment of the Multinational Stand-by High Readiness Brigade (SHIRBRIG)}

An initiative of the Danish and Canadian governments, SHIRBRIG is a rapidly deployable peacekeeping force at the UN's disposal. The brigade's estimated response time is of 15 to 30 days and it is comprised of 4000 to 5000 troops when fully deployed. Its purpose is to buy time to generate forces; it can remain in the field for up to six months. Since becoming operational in January 2000, SHIRBRIG was deployed to four missions (UNMEE, UNMIL, UNAMIS, and UNMIS). It also provided planning assistance to ECOWAS in Côte d'Ivoire and the DPKO in Darfur. According to a former commander of the brigade, SHIRBRIG has become an important element of peacekeeping operations and has proven an effective and efficient contributor to UN operations. While Canada's involvement in SHIRBRIG has diminished in recent years, the brigade remains operational and should be viewed as an additional tool for effectively responding to crises (Mitchell 2006; UNAC 2007).

\subsection{Canadian contributions to EU deployments}

Apart from these developments, Canada is also increasingly engaged with the EU in peace operations. The EU has become a global peace and security partner for Canada, with whom Canada enjoys much credibility. It is also in Canada's interest to have a secure Europe. Since 2003, Canada has contributed to four EU missions. At the 2007 Canada-EU Summit held in Berlin at the beginning of June, Canada agreed to participate in the new EU police mission to Afghanistan by deploying at least 22 police officers (Canada-EU Summit 2007). Canada could also possibly participate in the new police mission to the DRC (see Table 4).

Table 4: Canadian Contributions to EU Crisis Management Missions ${ }^{16}$

\begin{tabular}{|c|c|c|}
\hline $\begin{array}{l}\text { TYPE OF CRISIS } \\
\text { MANAGEMENT }\end{array}$ & CORRESPONDING MISSIONS & CONTRIBUTIONS \\
\hline \multirow{2}{*}{$\begin{array}{l}\text { MILITARY CRISIS } \\
\text { MANAGEMENT }\end{array}$} & $\begin{array}{l}\text { EUFOR Bunia, DRC (Operation } \\
\text { Artemis) }\end{array}$ & Strategic lift support. \\
\hline & - $\quad$ EUFOR in BiH (Operation Althea) & 8 (troop); ended March 2007 \\
\hline \multirow[t]{2}{*}{$\begin{array}{l}\text { CIVILIAN CRISIS } \\
\text { MANAGEMENT }\end{array}$} & EUPM in DRC (EUPOL Kinshasa) & $\begin{array}{l}1 \quad(\text { RCMP civilian); (ended } \\
\text { June 2007) }\end{array}$ \\
\hline & EUPM in $\mathrm{BiH}$ & 8 (police) \\
\hline
\end{tabular}

\footnotetext{
${ }^{15}$ At present, however, it is unclear when the force will become operational and how sustainable it will be in the field.

16 The numbers identified in Table 4 correspond to current Canadian commitments to EU missions (or commitment at time of mission closure). They are not an accurate representation of the total Canadian contribution to each EU mission.
} 


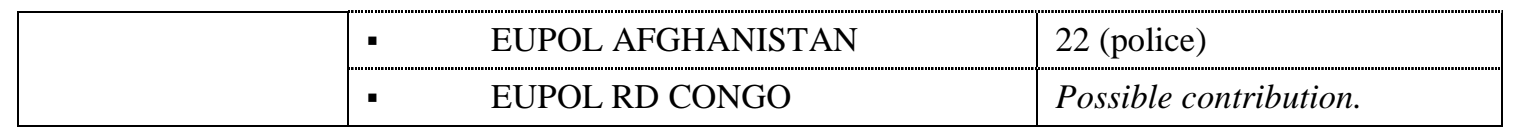

Source: Canadian Forces Operations 2007; RCMP International Peacekeeping 2007.

As part of its 2005 International Policy Statement (IPS), the Government of Canada pledged to continue working closely with the EU, and contribute to its missions. In following up on this commitment, Canada and the EU signed an "Agreement Establishing a Framework for the Participation of Canada in EU-Led Crisis Management Operations" in November 2005, which provides a blueprint for Canadian participation in EU military and civilian operations. The IPS also identified the capacity to respond to the challenge posed by state failure as a key component of Canada's defence strategy (Government of Canada 2005). This commitment to address weak or failing states is crucial in that it reasserts the goals of the European Security Strategy, and further justifies Canadian involvement in missions undertaken by the EU.

According to some scholars, however, Canadian participation in EU-led military operations does not serve Canadian interests. For Moens (2006), Canada's participation in Operation Althea, the largest Canadian contribution to an EU-led mission can be explained by the operation's reliance on a NATO-EU cooperation agreement (i.e., the Berlin Plus Agreement) and the fact that Canada did not have to choose sides. In his view, Canadian participation in a decision-making process that determines EU missions and objectives could never be meaningful simply because it is not an EU member. In his words, "Canadian military return from participating in EU-led operations is marginal at best," and he does not believe that "placing Canadian forces under the European Union in military operations [produces] an effective political or force multiplier for Canada" (Ibid.). By contrast, he acknowledges that combining Canadian and EU efforts in the areas of humanitarian, development and police coordination functions can be effective in getting results. If this is the case, it is not surprising then that Canada's military strategic interests are believed to be better served with NATO, as Canada is said to have more voice within NATO than within the EU (See Moens 2006). However, practice points to a different picture.

When looking at the list of Canadian contributions to EU missions (including potential future contributions), Canada appears more inclined to contribute to civilian missions than to military ones. While this may reflect a desire to retain command and control over its forces-as opposed to placing Canadian soldiers under the command of an organisation they are not a part of - the reality is that there has been much more opportunities to participate in civilian missions. Canada's close relationship with the EU is reflected in constant dialogue between Canadian and Council officials, at the political and technical levels. Canada is also recognized as an essential partner in crisis management, based on the expertise, professionalism and bilingualism of its personnel. Canada's contribution is always highly appreciated, especially in terms of what it doesn't bring to the table: a history of colonialism, a geographic proximity to belligerents, and a 
history of animosity of confrontation with parties to the conflict (Hamilton 2007). As a result, Canada's voice within the EU may not be as limited as some want us to believe. ${ }^{17}$ Notwithstanding the deepening level of cooperation between the EU and Canada, this relationship remains largely ad hoc and contributions modest in scale. Considering the strengths and added value that Canada can bring to EU missions, it is likely that Canada's participation in EU-led missions will continue in the future, particularly in civilian missions. These contributions are likely to remain modest in size, but will nevertheless serve to enhance EU missions positively.

\section{Conclusions: Implications for Hybrid Peacekeeping Missions in the Future}

At a time when the UN is more and more recognized as an 'indispensable' global actor in international peace and security, the surge in peacekeeping missions and financial demands has put an enormous strain on the organisation's ability to carry out ongoing missions and to undertake new ones (Brahimi 2006). Given the constraints placed on the $\mathrm{UN}$, the development of hybrid missions has become the preferred option for responding to emerging crises and increasingly complex post-conflict situations. This paper thus examined European Union and Canadian contributions to peace operations in an attempt to clarify the implication of their contributions for hybrid missions and for UN peacekeeping in general.

The above analysis demonstrates that hybrid missions involving the deployment of EU military and civilian capacities can help the UN in assuming its increasing role in conflict prevention and crisis management. While military deployments will be beneficial in providing for rapid and robust responses to crises and for supporting the UN in the event of growing instability, civilian capacities will prove beneficial in providing the UN with an integrated civilian package.

Apart from this progress, including improvements to formalize the EU-UN relationship, there is still confusion as to the exact nature of hybrid missions involving EU and UN components and their implications for conflict management. For example, future EU deployments in support of UN missions are not clear and predictable; some even argue that such contributions will remain "episodic and fragmented" (Liégois 2006, 160; own translation). This is especially the case for military deployments, as they do not yet provide for a full range of capabilities, leaving gaps to be filled by other actors. In addition, deployments must still be approved by individual EU member states, underlining the need for early exchanges of information and early engagement of states in the process. As Goulay $(2005,4)$ observes, "the challenge of institutionalising integrated and flexible responses in an EU context remains great, and will require creative practical solutions and continued support from member states for strengthening the EU's role and

\footnotetext{
${ }^{17}$ It is worth mentioning that the EU and Canada have recently agreed to establish cooperation on crisis response through START, and to continue to cooperate closely on EU election observation missions in order to allow participation by Canadian observers (Canada-EU Summit 2007). It is also important to note that both the EU and Canada are providing significant support to the African Union (AU), and particularly to the African Union Mission in Sudan (AMIS). This support-in the form of military and police advisers, logistical support, equipment, training, strategic lift, as well as financial resources-is crucial in that it supports AU peacekeeping missions in Africa, which in turn provides the UN with greater burden-sharing opportunities in responding to conflict.
} 
resources for civilian crisis management." The same can be said of military crisis management. Thus, while challenges remain, the growing number of ESDP missions gives a good idea of the willingness of the EU and its member states to get involved in peace operations and to support a multilateral approach with the UN at its center.

The above analysis also shows that Canada is in a unique position to cooperate with the EU to advance common interests. As a result, Canada should aim for a greater contribution to EU deployments where Canadian interests are best served. In doing so, both the EU and Canada should further develop the modalities for engaging Canada in EU missions. Greater Canadian engagement, combined with Canada's expertise and credibility, would enhance cooperation and coordination between the two entities, and could raise Canada's profile and voice within the EU and its institutions. Where the EU is not involved, but Canadian interests are at stake, Canada could pressure individual EU Members and other UN Members to use established frameworks such as SHIRBRIG.

The analysis also points to the need to strengthen UN capacity to undertake hybrid missions. In supporting hybrid missions, regional actors must ensure that the creation and build-up of regional capacities strengthen the UN organisation as a whole, rather than undermine it. This implies close cooperation and coordination between the UN and regional organisations, but also with single troop contributing countries such as Canada.

Moreover, while it is clear that hybrid missions can help to alleviate the UN's burden in peace and security, the 'hybridization' of UN peacekeeping operations should not constitute a reason for Western states to continue to avoid greater engagement in UN peace operations, both financially and in terms of military and civilian personnel. As Cottey and Forster (2004, 67) argue, "More equitable sharing of the burden of maintaining international peace and security [should be] a desirable goal in itself." Such equitable sharing will not only strengthen the legitimacy of peacekeeping in general, but may in the longer term, also help to develop "a wider consensus on sensitive questions of peace enforcement and intervention" (Ibid.).

To conclude, hybrid peacekeeping missions will likely prove advantageous in addressing the surge in the number, size and complexity of peace operations and in relieving the strain faced by the UN and the international community as a whole. As more actors acquire deployment capacity, more options are made available to the international community and the UN in conflict prevention and crisis management. More choices, in turn, can translate in a greater flexibility to choose the most suitable mechanism for a particular situation. In this regard, the flexibility of a hybrid model may in fact allow for more originality and context-specific solutions, and could help circumvent institutional rigidity when crafting responses (UNAC 2007). Thus, the best approach to the development of partnerships may be through the combination of established modalities for engaging with the UN and case-by-case analysis.

On a final note, it is worth mentioning that the strengthening of UN peacekeeping will only be possible through the active and sustained engagement of Western states to multilateralism and to the $\mathrm{UN}$ as a core actor in peace and security. 


\section{Bibliography}

Belliard, Jean-Christophe. 2007. Presentation given by Mr. Belliard, Task Force Afrique, European Council, March $1^{\text {st }}$.

Brahimi, Lakhdar. 2006. "UN Peace Operations in the $21^{\text {st }}$ Century: A Few Personal Thoughts." In Peacekeeping - Peacebuilding. Preparing for the Future, ed. Hanna Ojanen, 13-19. Helsinki: The Finnish Institute of International Affairs. Available at: www.upi-fiia.fi/doc/FIIA_report_14.pdf.

Canada-EU Summit Statement 2007, Berlin, 4 June 2007. Available at: www.eu2007.de/en/News/download_docs/Juni/0604-RAA1/010Erklaerung.pdf.

Center on International Cooperation (CIC). 2006. Annual Review of Global Peace Operations 2006. Boulder, CO: Lynne Rienner Publishers.

Choos, Jim. January 2007. "EU-UN co-operation on crisis management." European Security and Defence Policy Newsletter, no. 3. Brussels: European Council.

Cottey, Andrew and Anthony Forster. 2004. "Enhancing Regional Peacekeeping Capabilities." In Reshaping Defence Diplomacy: New Roles for Military Cooperation and Assistance (Adelphi Papers), 51-68. London: International Institute for Strategic Studies.

Dorn, Walter. December 2006. “Canada: The Once and Future Peacekeeper?” Peace $\begin{array}{lcr}\text { Magazine } 30 . & \text { Available }\end{array}$

http://peacejournalism.com/ReadArticle.asp?ArticleID=12227.

Durch, William and Tobias C. Berckman. 2006. "Définition et délimitation des opérations de paix." In Guide du maintien de la paix 2007, ed. Jocelyn Coulon, 1747. Québec: CEPES.

. 2006. Who Should Keep The Peace? Washington, D.C.: The Henri L. Stimson Center.

Earle, Caroline R.. March 2004. European Capacities for Peace Operations: Taking Stock. Washington, D.C.: The Henri L. Stimson Center.

Eide, Espen Barth. 2006. "From Peacekeeping to Peacebuilding." In Peacekeeping Peacebuilding. Preparing for the Future, 43-52.

European Council. 2007. "Security and Defence Policy." Available at: www.consilium.europa.eu/cms3 fo/showPage.asp?lang=EN.

Geneva Center for Security Policy (GCSP). 2003. EU and Peace Operations, Conference Proceedings, 22-23 September. 
Goulay, Catriona. March 2005. "EU Civilian Crisis Management: preparing for flexible and rapid response." European Security Review, No. 25. Brussels: Institute for Security and International Studies. Available at: www.isiseurope.org/ftp/Download/ESR25-CCM\%20final.pdf.

Government of Canada. 2005. Canada's International Policy Statement: A Role of Pride and Influence in the World-Defence. Ottawa: Government of Canada.

Graham, Kennedy. 2004. "Towards Effective Multilateralism - The EU and UN: Partners in Crisis Management." Issue no. 13. Brussels: European Policy Center (EPC). Available at: $\underline{w w w . i s n} . e t h z . c h / p u b s / p h / d e t a i l s . c f m ? \operatorname{lng}=e n \& i d=10822$.

Guicherd, Catherine. April 2006. "Reviving Chapter VIII: The United Nations and Regional Organisations - Partners for Peace." International Peace Academy meeting note, $1-12$.

Hamilton, Kevin. 2007. Remarks by Kevin Hamilton, Deputy Director, Conflict Prevention and Peacebuilding Group, Department of Foreign Affairs and International Trade at the " 3 rd Workshop on Enhancing Cooperation with Major Players in Conflict Prevention," hosted by the Madriaga European Foundation, Brussels, 19 April.

International Security Information Service (ISIS). July 2004. "Follow up to the European Security Strategy: Effective Multilateralism.” European Security Review, no. 23.

Jones, Bruce and Feryal Cherif. 2004. Evolving Models of Peackeeping, Policy Implications and Responses, report prepared for the United Nations Department of Peacekeeping Operations' Peacekeeping Best Practices Unit. New York, N.Y.: New York University Center on International Cooperation.

Leopold, Evelyn. 2006. "U.N. peacekeeping nearing 100,000 troops, civilians." Reuters, 5 October. Available at: http://hestar.com.my/news/story.asp?file=/2006/10/5/worldupdates/2006-1005T072950Z_01_NOOTR_RTRJONC_0_-270789-1\&sec=Worldupdates.

Liégois, Michel. 2006. "L'Union européenne et les operations de paix: l'arrivée à maturité d'un nouvel acteur?" In Guide du maintien de la paix 2007, ed. Jocelyn Coulon, 144-160. Québec: CEPES.

Mitchell, Gregory B. 2006. "Briefing to the Danish Institute of International Studies." Available at: www.diis.dk/graphics/Events/2006/SHIRBRIG/mitchell_briefing_diis.pdf.

Moens, Alexander. 2006. "Canadian Participation in EU-Led Military Operations Does not Serve Canadian Interest." The Dispatch 4, no. 2. Calgary: Canadian Defence 
and Foreign Affairs Institute. Avalailble at: www.cdfai.org/newsletters/newslettersummer2006.htm.

Royal Canadian Mounted Police (RCMP). 2007. "International Peace Operations Branch.” Available at: www.rcmp-grc.gc.ca/peace_operations/index_e.htm.

United Nations. March 2005. In Larger Freedom: towards development, security and human rights for all, Report of the Secretary General, A/59/2005. Available at: www.un.org/largerfreedom/.

. December 2004. A More Secured World: Our Shared Responsibility, Report of the Secretary General's High-Level Panel on Threats, Challenges and Change, A/59/565. Available at: www.un.org/secureworld/report2.pdf.

United Nations Association of Canada (UNAC). 2007. Peacekeeping to Peacebuilding: Lessons from the Past, Building for the Future. The Report on the UNA-Canada $50^{\text {th }}$ Anniversary of UN Peacekeeping International Panel Series 2006-2007. Ottawa: UNAC.

United Nations Department of Peacekeeping Operations (DPKO). 2007a. "Monthly Summary of Contributors of Military and Civilian Police Personnel." Available at: www.un.org/Depts/dpko/dpko/contributors/.

. 2007b. "United Nations Peacekeeping Operations." Available at: www.un.org/Depts/dpko/dpko/bnote.htm.

United Nations Department of Public Information (DPI). 2006. "United Nations Military, Police Deployment Reaches All-Time High In October." PKO/152. Available at: www.un.org/News/Press/docs/2006/pko152.doc.htm.

. 2007. United Nations Peace Operations Year in Review 2006. Available at: www.un.org/Depts/dpko/dpko/pub/year_review06/.

United Nations Office at Geneva (UNOG). 2006. Speech by Secretary General Kofi Annan at a Panel Discussion on the occasion of the International Day of United Nations Peacekeepers, Geneva, June $1^{\text {st }}$. Available at: www.unog.ch/unog/website/dg.nsf/(httpSpeechesByYear_en)/971583C641A6B776 $\underline{\mathrm{C} 12571810039 \mathrm{DE} 38 \text { ? OpenDocument } \& \text { year }=2006 .}$ 